\title{
Fatty Acid Profile of Captive Barb Fish (Barbonymus balleroides)
}

\author{
Syahfitri Anita ${ }^{1, *}$, Haryono Haryono ${ }^{1}$, and Gema Wahyudewantoro ${ }^{1}$ \\ ${ }^{1}$ Research center for Biology, Indonesian Insitute of Sciences, Gedung Widyasatwaloka, Jalan Raya Jakarta Bogor Km.46, Cibinong \\ Indonesia
}

\begin{abstract}
Barbonymus balleroides or barb fish is a freshwater fish that threaten by overexploitation and overfishing in their natural habitat. Our continuous investigation showed that fat content of barb fish that has been maintained in our pond facility for more than 1 year was decreasing. Since fatty acid (FA) is important property for farmed fish therefore it is essential to evaluate fatty acid profile of flesh and byproduct of captive Barb Fish. Captive fishes were originated from two different locations, Serayu River, Banjarnegara and Cipunagara River, Cianjur. FA composition of flesh and byproduct of fishes were analyzed using Gas Chromatography. Result showed that both flesh and byproduct of both origin contained good quality of FA particularly omega 3 and omega 6 and other beneficial unsaturated fat, omega 9 . However captive barb fish showed lower FA composition than wild barb fish that could be influenced by its feed and other environmental parameter. The high composition of FA in barb fish byproduct indicated its potency to be utilized further for nutrition source. This study showed the needed to make further improvement in barb fish cultivation so that it could produces high quality farmed fish.
\end{abstract}

\section{Introduction}

Barbonymus balleroides or barb fish is a freshwater fish live in fast-flowing river. It is an omnivore fish that consume phytoplankton, aquatic plants, detritus, insects, pieces of fish, gastropods, and crustaceans [1]. Geographically, the fish is distributed in Java and Kalimantan islands [2-4]. Previous study has shown that there is an indication of overexploitation and overfishing activity in Serayu River, Banjarnegara [5]. In some area of Java Island, this fish is already difficult to find possibly due to overfishing and environmental damage [6]. This pressure could threaten barb's population in their natural habitat. On the other hand, overfishing activity indicates high consumer preference and showed potency for developing this fish as aquaculture commodity.

Fish quality as food source commonly evaluated based on several parameter such as texture, color and also their nutritional component. These qualities in the farmed or wild fish even in the same species could be different as shown in several studies [7-11]. Consumer belief about different quality of farmed and wild fish could influence their preference even though without underlying scientific knowledge. Therefore providing consumers with reliable information that helps them to value the farmed and wild fish based on scientific evidences would be needed [12]. Several studies showed that the nutritional quality of fish can fluctuate widely due to species [13], diet [8], location [14], sex [15], and season [16].
Wild barb fish from Serayu River, Banjarnegara and Cipunagara River, Cianjur could survive in our pond facility and has succeeded in producing the first offspring [17]. In our previous study, we have evaluated the nutritional content of wild barb fish [18]. This study showed that wild barb fish contained valuable nutrition for human health with high content of protein. However, our continuous investigation showed that fat content of barb fish that has been maintained for more than 1 year was decreasing to about $1 / 4$ of wild fish fat content [19]. Since fatty acid (FA) is important property in fish consumption and also being sought for human nutrition, therefore it is essential to evaluate fatty acid profile. In this study, we aimed to evaluate fatty acid profile of captive barb fish that has been maintained in our pond facility for about 1.5 year.

\section{Material and methods}

\subsection{Fish collection and maintenance}

Fishes were originated from two locations, which is Serayu River, Banjarnegara, Central Java, and Cipunagara River, Sumedang City, West Java. Both habitats characterize by flowing stream, rocky bottom bed, composed of sand and gravel substrate. Fishing sites were also characterized by $\mathrm{pH} 7-8$, temperature $24-31^{\circ} \mathrm{C}$ and the concentration of dissolved oxygen around 4.1$8.3 \mathrm{ppm}$. Fishes were catch using cast and gill net, a traditional fishing instrument that commonly used by local people around the habitat.

\footnotetext{
Corresponding author: syafiet@gmail.com
} 
Fishes were maintained in 1.80 meter depth pond, filled with water that was pumped from the pond. Fishes were fed with commercial feed, Hi - Pro - Vite from PT. Central Pangan Pertiwi, and papaya leaves (ad libitum). We also found some Crustaceae (Acetes sp.) in pond water which possibly also eaten by the fishes. The commercial feed contained about $31-33 \%$ protein, $3-5 \%$ fat, $4-6 \%$ fiber, $10-13 \%$ ash, and $11-13 \%$ water. During the period of collection, we measure the physical parameter of the pond environment. The measurement was conducted for 3 times for 3 consecutive days with each measurement was performed in duplo.

\subsection{Sample preparation}

Caught fishes were, dissected and cleaned with running water. Body parts were divided into flesh (with skin attached) and byproducts (head, fin, bones, and tail). All these parts were cut into small pieces, dried either with oven at $65^{\circ} \mathrm{C}$ or freeze dried and then stored in $-20^{\circ} \mathrm{C}$ before further testing.

\subsection{Fatty acid determination}

Fatty acid was analyzed followed AOAC (2000) [20]. Fat extraction was conducted using soxhlet extraction with hexane as solvent and converted into methyl esters by reaction with methanol and $\mathrm{KOH}$ as a base catalyst. The second methylation was conducted using BF3 as an acid catalyst. Methyl esters was then analyzed with GC FID Clarus 580 Perkin Elmer. Samples were analyzed using nitrogen as the carrier gas and Supelco SPTM 2560 column. The initial temperature of the column was set and held at $100^{\circ} \mathrm{C}$ for $3 \mathrm{~min}$, and then raised at $2.5^{\circ} \mathrm{C} /$ minute to $240^{\circ} \mathrm{C}$ which was held for $23 \mathrm{~min}$. The fatty acid component was quantified by comparing each peak area with total peak areas and then expressed as a percentage of total fatty acid quantified.

Table 1. Physical parameter of fish maintenance pond

\begin{tabular}{|l|l|}
\hline Parameter & Range $(\mathrm{n}=9)$ \\
\hline DO $(\mathrm{mg} / \mathrm{L})$ & $6.9-8.8$ \\
\hline Temperature $\left({ }^{\circ} \mathrm{C}\right)$ & $27.3-32.4$ \\
\hline $\mathrm{pH}$ & $6-7$ \\
\hline Water color & Greenish \\
\hline Pond depth $(\mathrm{cm})$ & $64-76$ \\
\hline
\end{tabular}

\section{Results and Discussion}

\subsection{Results}

Measurement of physical parameter of pond environment are describe in Table 1. Table 2. showed the fatty acid profile of flesh and byproduct of barb fish after being maintenance for 1.5 year in our pond facility. In this table, we also showed the fatty acid profile of wild barb fish from our previous study. Overall this result showed that fatty acid content from flesh barb fish in maintenance pond was lower than the fatty acid of wild barb fish flesh except for the content of C 22:6 13 DHA. There is no information on byproduct FA of wild fish, thus we cannot make any comparison. However, this result showed that byproduct of fish that often not consumed and being wasted is still contain good composition of FA.

Comparison of flesh fatty acid content showed that Serayu barb fish contained more fatty acid than from Cipunagara. Flesh of barb fish from Banjarnegara were composed of $2.7983 \%$ of total saturated fatty acid (SFA), $2.6935 \%$ of monounsaturated fatty acids (MUFA) and $2.0913 \%$ polyunsaturated fatty acids (PUFA). Meanwhile, flesh of barb fish from Cipunagara contained $1.3978 \%$ SFA, $1.1547 \%$ MUFA and $1.0146 \%$ PUFA. Total unsaturated fatty acids were higher than saturated fatty acids in both samples. Among saturated fatty acid, palmitic acid (C16:0) was the most dominant in both samples which still in line with previous finding. The most dominant MUFA found in both samples were oleic acid (C 18:1 $\omega 9 \mathrm{c})$.

Byproduct fatty acid profile of barb fish showed that it contains more fatty acid compare to its flesh. Exception was observed for the content of C 20:4 16 AA of flesh Serayu that was higher than its byproduct. It was shown that byproduct of Barb fish from Serayu composed of $4.6500 \%$ of total saturated fatty acid (SFA), $4.5449 \%$ of monounsaturated fatty acids (MUFA) and $2.9883 \%$ polyunsaturated fatty acids (PUFA). Meanwhile, byproduct of Barb fish from Cipunagara contained $6.5126 \%$ SFA, 5.9020\% MUFA and 3.5225\% PUFA. Total unsaturated fatty acids were higher than saturated fatty acids in both samples with the same pattern of its flesh where palmitic acid $(\mathrm{C} 16: 0)$ was the most dominant saturated fatty acid. It was also found that total SFA, MUFA and PUFA of byproduct barb fish from Cipunagara was higher than Serayu. The highest MUFA found in both samples were oleic acid (C

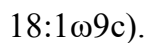

Flesh and byproduct of barb fish from both locations also contained essential fatty acid, omega 3 and omega 6 and other beneficial unsaturated fat, omega 9. Omega 9 was found in comparable amount compare to omega 3 and 6 and particularly contributed by the amount of oleic

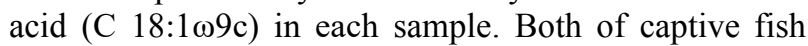
flesh sample contained omega 6 and 9 that lower than wild barb fish flesh. Omega 3 was found higher in the captive fish from Serayu compare to its wild fish and was found highest in wild fish from Cipunagara. Omega 3 in all samples was found composed of DHA, EPA and ALA. Omega 6 in all samples was composed of linoleic

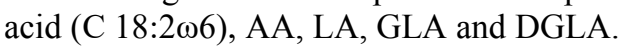

\subsection{Discussion}

Fish is considered a nutritious food that mostly pursued for its protein content and also essential fatty acid. Fish is known as the primary source of a long chain of PUFAs as this type of fatty acid plays an essential role in immune system regulation, blood clots, neurotransmitters, cholesterol metabolism, and structure of membrane phospholipids in the brain and the retina [21]. 
Table 2. Fatty acid profile of Barb fish flesh and byproduct

\begin{tabular}{|c|c|c|c|c|c|c|c|}
\hline \multirow{2}{*}{ NO } & \multirow{2}{*}{ Variable } & \multicolumn{2}{|c|}{$\operatorname{Flesh}^{1}(\%)$} & \multicolumn{2}{|c|}{ Flesh $^{2}(\%)$} & \multicolumn{2}{|c|}{ Byproduct $^{1}(\%)$} \\
\hline & & MFFB & MFFC & WFFB & WFFC & MFBB & MFBC \\
\hline 1 & C 12:0 & 0.0116 & 0.0146 & 0.1297 & 0.1584 & 0.0266 & 0.0267 \\
\hline 2 & C 14:0 & 0.1271 & 0.0631 & 0.2313 & 0.4393 & 0.2562 & 0.3115 \\
\hline 3 & C 15:0 & 0.0200 & 0.0090 & 0.0225 & 0.0380 & 0.0375 & 0.0426 \\
\hline 4 & C 16:0 & 1.9520 & 0.9040 & 3.0918 & 5.7463 & 3.3119 & 4.4365 \\
\hline 5 & C 17:0 & 0.0366 & 0.0192 & 0.0323 & 0.0576 & 0.0612 & 0.0896 \\
\hline 6 & C 18:0 & 0.5851 & 0.3758 & 0.7551 & 1.6937 & 0.8658 & 1.5583 \\
\hline 7 & C 20:0 & 0.0182 & 0.0092 & 0.0285 & 0.0447 & 0.0229 & 0.0443 \\
\hline 8 & C 21:0 & 0.0425 & nd & 0.0043 & 0.0057 & 0.0566 & nd \\
\hline 9 & C 23:0 & 0.0053 & nd & 0.0027 & 0.0050 & 0.0092 & nd \\
\hline 10 & C $15: 1$ & 0.0178 & 0.0217 & 0.0027 & nd & 0.0214 & 0.0247 \\
\hline 11 & C $16: 1$ & 0.0734 & 0.0322 & 0.2292 & 0.3149 & 0.1519 & 0.1768 \\
\hline 12 & C $17: 1$ & 0.0138 & 0.0213 & 0.0219 & 0.0311 & 0.0283 & 0.0424 \\
\hline 13 & C $18: 1 \omega 9 c$ & 2.5083 & 1.0269 & 3.3204 & 6.7995 & 4.2359 & 5.4518 \\
\hline 14 & C 20:1 & 0.0463 & 0.0297 & 0.0266 & 0.0408 & 0.0636 & 0.1609 \\
\hline 15 & C $24: 1 \omega 9$ & 0.0329 & 0.0229 & 0.0038 & 0.0077 & 0.0408 & 0.0434 \\
\hline 16 & C $18: 2 \omega 6$ & 1.3094 & 0.5818 & 1.9496 & 3.2200 & 2.1115 & 2.5670 \\
\hline 17 & C $18: 2 \omega 6 c$ LA & 1.3094 & 0.5818 & 1.9496 & 3.2200 & 2.1115 & 2.5670 \\
\hline 18 & C $18: 3 \omega 3$ ALA & 0.1170 & 0.0516 & 0.1001 & 0.1872 & 0.2290 & 0.2711 \\
\hline 19 & C $18: 3 \omega 6$ GLA & 0.0177 & 0.0030 & 0.0646 & 0.0651 & 0.0305 & 0.0208 \\
\hline 20 & C $20: 2$ & nd & 0.0186 & 0.0072 & 0.0089 & nd & 0.0603 \\
\hline 21 & C 20:3 $\omega 6$ DGLA & 0.0588 & 0.0249 & 0.0880 & 0.1349 & 0.0633 & 0.0597 \\
\hline 22 & C $20: 4 \omega 6$ AA & 0.2040 & 0.0930 & 0.2853 & 0.2097 & 0.1597 & 0.1267 \\
\hline 23 & C $20: 5 \omega 3$ EPA & 0.0455 & 0.0328 & 0.0255 & 0.0696 & 0.0465 & 0.0753 \\
\hline 24 & 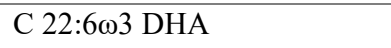 & 0.3389 & 0.2039 & 0.2294 & 0.2689 & 0.3477 & 0.3416 \\
\hline 25 & Total Unsaturated Fatty Acid & 4.7848 & 2.1692 & 6.3710 & 11.4072 & 7.5331 & 9.4244 \\
\hline 26 & Total SFA & 2.7983 & 1.3978 & 4.3041 & 8.1999 & 4.6500 & 6.5126 \\
\hline 27 & Total MUFA & 2.6935 & 1.1547 & 3.6146 & 7.2232 & 4.5449 & 5.9020 \\
\hline 28 & Total PUFA & 2.0913 & 1.0146 & 2.7546 & 4.1840 & 2.9883 & 3.5225 \\
\hline 29 & $\omega 9$ & 2.5083 & 1.0269 & 3.3257 & 6.8212 & 4.2359 & 5.4518 \\
\hline 30 & $\omega 6$ & 1.5899 & 0.7027 & 2.3876 & 3.6296 & 2.3651 & 2.7742 \\
\hline 31 & $\omega 3$ & 0.5014 & 0.2933 & 0.3567 & 0.5327 & 0.6232 & 0.6880 \\
\hline 32 & $\omega 6 / \omega 3$ & 3.1709 & 2.3958 & 6.6936 & 6.8136 & 3.7951 & 4.0323 \\
\hline
\end{tabular}

MFFB: Flesh of captive fish originate from Serayu River, MFFC: Flesh of captive fish originate from Cipunagara River, WFFB: Flesh of wild fish from Serayu River, WFFC: Flesh of wild fish originate from Cipunagara River, MFBB: Byproduct of captive fish originate from Banjarnegara, MFBC: Byproduct of captive fish originate from Cipunagara River. ${ }^{1}$ Result from this study, ${ }^{2}$ Result from previous study [18] that shown here as comparison. nd: not detected.

Fish FA that considered important and desirable are omega 3 and 6 . Omega 3, particularly in the form of DHA and EPA, has been demonstrated as essential for the growth and functional development of the infant's brain and also required for normal brain function maintenance in adults and has been linked to the prevention and treatment of numerous inflammatory diseases (cancers and heart disease) [22-24]. Intake of omega 3 and omega 6 is suggested to be balanced and the omega-6/omega-3 ( $\omega 6 / \omega 3)$ ratios is known as important nutrition index for assessing the balanced synthesis of eicosanoids in the body [26]. Our previous study showed that $\omega 6 / \omega 3$ ratio of Barb fish flesh from both fishing locations was relatively similar [18]. Compare to those previous study, it was shown that $\omega 6 / \omega 3$ of captive barb fish was lower than the wild barb fish. However, the $\omega 6 / \omega 3$ ratio of Barb fish still indicate that the fish is good for nutrition source since the ratio 
was low compared to other food that could affect diseases such as cardiovascular or breast cancer [25]. A high proportion of omega 6 , that mainly composed of linoleic acid (LA) and arachidonic acid (AA), is known as a characterization of freshwater fish that could be attributed to the type of diet [26]. As shown by study on lipid and fatty acid comparison of marine and freshwater fish that found higher omega 6 content on freshwater fish than marine fish [27].

Among saturated FA, palmitic acid (C16:0) was the highest FA found in each sample, this finding was in line with a study about freshwater fish from Greece and south Brazil that found palmitic acid as one of the dominant fatty acids in the sample [28, 29]. The most dominant MUFA found in both samples were oleic acid (C18:1). The high level of C18:1 FA could be said as a typical character of fish muscle which has been reported in numerous freshwater and marine fishes such as Capoeta damascina [30], Sparus aurata [31], Boops boops, Trachurus mediterraneous, Pagellus erythrinus, Scorpaena scrofa, Scopthalmus maeticus, Solea solea [32], Thunnus albacares, Thunnus obesus [33], Seriola dumerili [10, 34], Pangasius bocourti [35], seriola lalandi [36] and numerous cultured freshwater and marine fish and shrimp from China [37]. Other important feature of FA profile in Barb fish is the presence of arachidonic acid (C20:4) which known as an important component in the wound healing process for facilitating blood clotting and attachment to endothelial cell [38].

The fatty acid composition of freshwater fish was influenced by lipid pattern of their natural food and environmental condition. Several study showed a close relationships between fish lipid composition and the diets of fish [39, 40]. For example, carp fish on a diet with essential fatty acid accumulated long-chain PUFA such as docosahexenoic acid in response to cold temperature [41]. Salinity could also change essential FA compositions of fish where it caused statistically significant differences in the fatty acid composition of muscle tissue of fish being fed with the same diet [42]. Lower content of FA, particularly for the $\omega 3$ and $\omega 6$, in captive barb fish compare to wild barb fish could be influenced by their diet. As it is known that fish are unable to synthesize any fatty acids of the $\omega 3$ and $\omega 6$ series unless a precursor with this $\omega$ structure is present in the diet, however, fish are able to desaturate and elongate fatty acids of the $\omega 3, \omega 6$ or $\omega 9$ series [43].

The commercial feed used in the maintenance pond compose of high protein and low fat (31-33\% protein, 3 $5 \%$ fat). One of feed that known have role as source of fatty acid is phytoplankton. Study conducted by Rumondang [1] in Serayu River showed that wild Barb fish was lives in water which contained around 101 species of phytoplankton. Different amount and type of phytoplankton lives in the pond could possibly changes the FA composition. In their natural habitat, barb fish feed on plant parts, insect, crustaceae, protozoa, detritus, zooplankton, periphyton in the bacillariophyceae, cyanophyceae, myxophyceae, rhodophyceae, cryptoceae classes [44]. Other factor that could be related such as the physical and chemical parameter of the water. Wild barb fish known lives in freshwater characterized by $\mathrm{pH}$
$7-8$, temperature $24-31^{\circ} \mathrm{C}$ and the concentration of dissolved oxygen around 4.1-8.3 ppm which was different with the pond condition (Table 1). However more detailed study is needed to establish the significant factor that affected the FA composition in captive Barb fish.

Byproduct part in this study was mainly composed of fish bone, head and tail. Information about chemical property of fish bone is still limited but is interesting to be discussed particularly for understanding its physiological role and also for its further utilization since a lot of portion of this part is often wasted. Byproduct of captive barb fish studied here contained relatively higher FA composition than its flesh part. This result possibly is in line with our previous study that showed byproduct part contained higher fat than its flesh [18]. FA profile contained in the byproduct indicate that this part of fish which often wasted have a potency to be developed further into a valuable product. For example as feed for other fishes as shown is the study using dried fish bones as feed ingredient in diets for cod, showing a positive effect on growth and feed efficiency compared to traditional diets [45].

Very little study that has described fish bone FA composition. Lee et al. [46] reported that $64-97 \%$ of total bone oil was triglycerides consisting mainly of the fatty acids 18:1, 16:0 and 16:1 in addition to the PUFA 20:5 and 22:6 which also in good correspondence with study conducted by [47]. Some of this was in line with our result, however we found that 18:2 FA is the highest PUFA. The amount of fat content in the byproducts could also related to a lipid storage type of fish. For example, the fatty fish; salmon, trout, herring and mackerel, that store lipid in the muscle, have a much higher content of lipids in bones compared to the lean fish; cod, saithe and blue whiting that store lipid in the liver [47]. However, from fat content of flesh Barb fish showed in the previous study [18], that was in the range $5-10 \%$ shows that barb fish could be categorized as fish with medium fat.

\section{Conclusion}

This study showed that Barb fish maintain in pond facility contained good FA for human health and nutrition. Captive barb fish showed lower FA composition than wild barb fish that could be related with feed and other environmental parameter. The FA profile in byproduct of barb fish indicated its potency to be utilized further. Fish maintenance held in this study was more directed toward hatchery and breeding to cultivate the first offspring (domestication program). This makes the nutritional content of fish was not a main concern. However since this fish will be served as human food source therefore further improvement in their environmental condition and feeding input should be considered so that it could produces high quality farmed fish.

The author's thanks Mrs. Tri H Handayani, Mrs. R. Lia R. Amalia and Mr. Rudi for their helpful assistance. The Research 
Center for Biology supported this research through 2019 DIPA program Indonesian Institute of Sciences.

\section{References}

1. Rumondang. Kajian Makanan dan Pertumbuhan Ikan Brek (Barbonymus balleroides Val. 1842) di Sungai Serayu Kabupaten Banjarnegara Provinsi Jawa Tengah (2013)

2. M.L.F. Weber, de Beaufort. The Fishes of the IndoAustralian Archipelago Ostariophysi: II. Cyprinoidea Apodes, Synbrachii. E.J. Brill. Netherlands (1916)

3. T. R. Robert, The Freshwater Fishes of Java, as Observed by Kuhl and van Hesselt in 1820-1823. Zoologische Verhandelingen, 285, 1-94 (1993)

4. M. Kottelat, A.J. Whitten, S.N. Kartikasari, S. Wirjoatmodjo. Freshwater Fishes of Western Indonesia and Sulawesi (1993)

5. Rumondang. Agricola, 6, 1-12 (2016)

6. Haryono. (2015). Barb fish management (Barbonymus Balleroides Val. 1842) based on ecobiology aspect in upstream area of Serayu River Central Java (2015)

7. C. Cahu, P. Salen, M. de Lorgeril, Nutr Metab Cardiovasc Dis, 14, 34-41 (2004) https://doi.org/10.1016/s0939-4753(04)80045-0

8. A. Fuentes, I. Fernandez-Segovia, J.A. Serra, J.M. Barat. Food Chemi, 119, 1514-1518 (2010) https://doi.org/10.1016/j.foodchem.2009.09.036

9. M. Krajnović-Ozretić, M. Najdek, B. Ozretiić. Comp Biochem Phys A, 3, 611-617 (1994)

10. D. Rodríguez-Barreto, S. Jerez, J.R. Cejas, M.V. Martin, N.G. Acosta, A. Bolaños, A. Lorenzo. Aquaculture, $\quad 360-361, \quad 1-9 \quad$ (2012) http://dx.doi.org/10.1016/j.aquaculture.2012.07.013

11. F. Zhao., P. Zhuang, L. Zhang, Z. Shi, Z. Fish Pysiol Biochem, 36, 1105-1111, (2010). https://doi.org/10.1007/s10695-010-9388-5

12. A. Claret, L. Guerrero, I. Gartzia, M. Garciaquiroga, \& R. Ginés, Aquaculture, 454, 157-162 (2016) https://doi.org/10.1016/j.aquaculture.2015.12.024

13. A.A Nurnadia, A. Azrina, I. Amin, I., A.S. Mohd Yunus, H. Mohd Izuan Effendi, Int. Food Res. J. 20. 431-437. https://doi.org/10.1016/j.aquaculture.2015.12.024

14. G. Medina, L. Castro, S. Pantoja, Fish Res, 160, 4149

https://doi.org/10.1016/j.fishres.2013.11.005

15. F. Norambuena, A. Esteves, G. Bell, I. Carazo, N. Duncan, (2012). Aquaculture, 356-357, 176-185. https://doi.org/10.1016/j.aquaculture.2012.05.018

16. V. Šimat, T. Bogdanović, Acta Adriatica, 53, 125132 (2012).

17. Haryono G. Wahyudewantoro. Domestikasi ikan brek (Barbonymus balleroides) untuk konservasi dan diversifikasi ikan budidaya, 71-81. 2019.

18. S. Anita, Haryono, G. Wahyudewantoro, Biodiversitas, 20, 581-588 (2019). https://doi.org/10.13057/biodiv/d200239
19. Anita, S., T.H. Handayani, R.L.R. Amalia. Domestikasi ikan brek (Barbonymus balleroides) untuk konservasi dan diversifikasi ikan budidaya. 13-25 (2019)

20. AOAC. Official Method of Analysis, Oil and Fat, 26-28 (2000)

21. E. Abedi, M.A. Sahari, Food Nutr Sci, 2, 443-463 (2014). https://doi.org/10.1002/fsn3.121

22. L.A. Horrocks, Y.K. Yeo, Pharmacol Res, 40, 211 225 (1999) https://doi.org/10.1006/phrs.1999.0495

23. P.C. Calder, Biochim Biophys Acta. 1851, 469-484 (2015) https://doi.org/10.1016/j.bbalip.2014.08.010

24. D. Kromhout, S. Yasuda, J.M. Geleijnse, H. Shimokawa, Eur Heart J, 33, 436-443 (2012) https://doi.org/10.1093/eurheartj/ehr362

25. A.P. Simopoulos, Biomed Pharmacoter, 56, 365-379 (2002). 3322(02)00253-6

https://doi.org/10.1016/s0753-

26. W. Steffens, Aquaculture, 151, 97-119 (1997). https://doi.org/10.1016/S0044-8486(96)01493-7

27. Y. Ozogul, F. Ozogul, S. Alagoz, Food Chem, 103, 217-223 https://doi.org/10.1016/j.foodchem.2006.08.009

28. G. Aggelousis, E.S. Lazos,. J Food Compos Anal, 4, 68-76 (1991) https://doi.org/10.1016/08891575(91)90049-C

29. A.D. Andrade, A.F. Rubira, M. Matsushita, N.E. Souza. J Am Oil Chem, 72, 1207-1210 (1995). https://doi.org/10.1016/s0753-3322(02)00253-6

30. A.A. Fallah, A. Nematollahi, S.S. Saei-Dehkordi, J Food Compos Anal , 32, 150-154 (2013) https://doi.org/10.1016/j.jfca.2013.09.004

31. A. Mnari, I. Bouhlel, I. Chraief, M. Hammami, M.S. Romdhane, M. El Cafsi, A. Chaouch, Food Chem, 100, 1393-1397 (2007) https://doi.org/10.1016/j.foodchem.2005.11.030

32. Y. Özgoul, F. Özogul,. Food Chemistry, 100, 1634 1638 https://doi.org/10.1016/j.foodchem.2005.11.047

33. S. Peng, C. Chen, Z. Shi, L. Wang, J Food Nutr Res, 1, 42-45 (2013) https://doi.org/10.12691/jfnr-1-4-2

34. D. Rodríguez-Barreto, S. Jerez, J.R. Cejas, M.V. Martin, N.G. Acosta, A. Bolaños, A., Eur J Lipid Sci Tech, 116, 584-595 (2014) https://doi.org/10.1002/ejlt.201300462

35. P. Thammapat, P. Raviyan, S. Siriamornpun, Food Chemistry, 122, 223-227 (2010) https://doi.org/10.1016/j.foodchem.2010.02.065

36. B. O’Neill, A. Le Roux, L.C. Hoffman. Aquaculture, 448, 169-175 (2015) https://doi.org/10.1016/j.aquaculture.2015.05.034

37. G. Li, A.J. Sinclair, D. Li,.J Agric Food Chem, 59, 1871-1881

(2011). https://doi.org/10.1021/jf104154q

38. S.A. Rahman, T.S. Huah, O. Hassan, N.M. Daud. Food Chem, 54, 45-49 (1995) https://doi.org/10.1016/0308-8146(95)92660-C

39. J.D. Castell, Finfish Nutrition and Fish feed Technology, 59-84 (1979)

40. I.C. Chen, F.A Chapman, C.I. Wei, K.M. Porteir, S.F. O'Keefe, J Food Sci, 60, 631-635 (1995) https://doi.org/10.1111/j.1365-2621.1995.tb09844.x 
41. T. Farkas, I. Csengeri, F. Majoros, J. Ola'h, Aquaculture, 20, 29-40 (1980) https://doi.org/10.1016/0044-8486(80)90059-9

42. H.I Haliloğlu, A. Bayir, A.N. Sirkecioğlu, N.M. Aras, M. Atamanalp, Food Chem, 86, 55-59 (2004) https://doi.org/10.1016/j.foodchem.2003.08.028

43. J.E. Halver, Lipids and Fatty Acids. In Fish Feed Technology,

(1980)

http://www.fao.org/3/x5738e/x5738e05.htm

44. Sriati, Telaah Strategi Adaptasi Ikan Lalawak (Puntius bromides), Cuvier dan Valenciennes, Dalam Kaitannya Dengan Pengelolaan Bendung
Curug Kabupaten Karawang, Propinsi Jawa Barat. (1987)

45. J. Toppe, A. Aksnes, B. Hope, S. Albrektsen, Aquaculture, 253, 636-645 (2006) https://doi.org/10.1016/j.aquaculture.2005.09.015

46. R.F. Lee, C.F. Phleger, M.H. Horn, Comp Biochem Physiol B Biochem Mol Biol, 50, 13-16 (1975) https://doi.org/10.1016/0305-0491(75)90291-6

47. J. Toppe, S. Albrektsen, B. Hope, A. Aksnes, 146 395-340 